\title{
APPLICATION OF ELECTRICAL RESISTIVITY TOMOGRAPHY (ERT) IN THE INVESTIGATION OF QUATERNARY LANDSLIDE ZONES, BASED ON THE SELECTED REGIONS OF PLOCK SLOPE
}

\author{
Lukasz Kaczmarek $^{1}$, Radosław Mieszkowski ${ }^{1}$, Marcin Kołpaczyński ${ }^{2}$, Grzegorz Pacanowski ${ }^{3}$ \\ ${ }^{1}$ University of Warsaw, Faculty of Geology, Institute of Hydrogeology and Engineering Geology, \\ Żwirki i Wigury 93,02-089Warsaw,e-mails: lukasz.kaczmarek@uw.edu.pl,r.mieszkowski@uw.edu.pl \\ ${ }^{2}$ Geotechnika Mazowsze s.c., Żwirki i Wigury 93, room 3030 (building of the Faculty of Geology of the \\ University of Warsaw),02-089 Warsaw, e-mail: biuro@geotechnika-mazowsze.pl \\ 3 Polish Geological Institute - Polish Research Institute, Rakowiecka 4, 00-975 Warsaw, \\ e-mail: grzegorz.pacanowski@pgi.gov.pl
}

\begin{abstract}
The article shows the results of geophysical surveys performed by using Electrical Resistivity Tomography (ERT) method on selected ragion of Płock slope of a Tumski hill near Basilica of Assumption of the Blessed Virgin Mary in Płock and in Maszewo by the Vistula River a few kilometers north of Płock. The above-mentioned sections were selected due to landslide phenomena observed there. Geophysical surveys were conducted in order to verify the state of the distribution of electrical resistivity in the sectors where mass movement was identified. The electrofusion crosssection near Cathedral Basilica shows clays and sands. Also in ERT prospection a zone of loose soils with high resistance is clearly visible. The results of the ERT method from Maszewo, indicates historical land surface of a landslide and that the slope in Maszewo consists of cohesive deposits. In order to describe these particular issues, geological cross-sections and safety factor obtained by calculation are presented for the analyzed parts of the slope. The safety factor shows that probability of landslide activity near Cathedral Basilica is very unlikely and in Maszewo is very high.
\end{abstract}

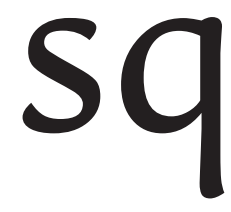

Key words: slope stability, the Płock slope, Electrical Resistivity Tomography (ERT), quaternary.

Manuscript received 30 April 2014, accepted 19 October 2014

\section{INTRODUCTION}

Płock is situated at the western slope edge of the Plateau Płońska, which was created by glacial processes. To the south-west of the slope lies a valley of the Vistula river. The slope in the area in question runs from the south-east to the north-west, along the Vistula river.

Since the twelfth century the Płock slope (Fig. 1), which is the western edge of the Tumski Hill (Old Town) is the location for sacral caste complex.

The slope is result of the Vistula river lateral erosion on the fragment from $630 \mathrm{~km}$ to $655 \mathrm{~km}$ of the river flow (Wysokiński 1998). In the further part of the river, beyond city centre, in Maszewo region, the river creates areas of extraordinary natural beauty, which are being urbanized along the upper edge of the Płock slope. The height of the slope varies, from $30 \mathrm{~m}$ in Maszewo to $42 \mathrm{~m}$ in the city of Płock.

Urbanization ratio in the area of the slope increases with time. From the static load point of view this represents an increase of forces increasing the probability of landslides.

In order to achieve objective of this study, that is to verify the distribution of electrical resistivity of soil in areas as- sociated with mass movements, two fragments of the Płocks slope were selected.

1. Area of the Cathedral Basilica of the Ascendance in Płock

2. Area in Maszewo, $2 \mathrm{~km}$ north of Płock

In the abovementioned places geophysical surveys were performed by using electrical resistivity tomography (ERT). In such places, with recognized geological structure, values of the equilibrium factor were also determined slopes.

\section{HISTORY OF GEOPHYSICAL RESEARCH IN THE LANDSLIDE AREAS}

The use of geophysical methods to study landslides started in the ' 60 s and ' 70 s of the twentieth century (Keller et al. 1966, Bogoslovsky et al. 1977). The focus was put mainly on the method of seismic and electrical resistivity. Currently, the use of geophysical methods (mainly methods ERT) to study contemporary landslides concentrates on the determination of colluvial zones, slip surface, staging of landslides and soil-water conditions in the vicinity of the slope. Numerous examples of the application of ERT method for testing 


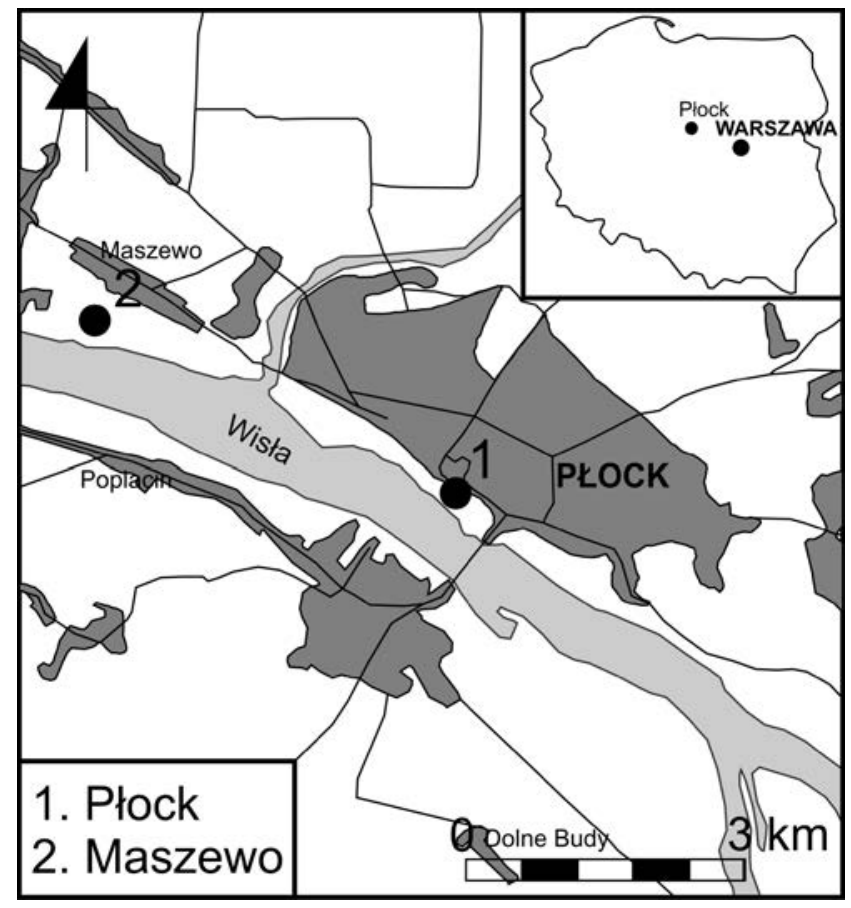

Fig. 1. Location of selected fragments of the Płock slope (www. geoportal.gov.pl).

slopes can be found in multiple geo-engineering publications, e.g.: Hack 2000, Lapenna et al. 2005, Le Roux et al. 2011, Marescot et al. 2008, Mauritsch et al. 2000, McCann and Forster 1990, Perrone et al. 2004, Göktürkler et al. 2008, Gaudio and Bottino 2001, Friedel et al. 2006, Bichler et al. 2004).

Many landslides are characterized by the presence in the toe of landslide fragments of rock blocks. Among various publications on ERT method there are known works, where ERT is used to identify older rock blocks in the subsurface covered with younger layer sediments and slide drops (e.g. Socco et al. 2010, Tetegan et al. 2012). In Poland geophysical methods (seismic and ERT ) are also used to analyze slopes, embankments and landslide zones in accordance with the recommendations made in the works of Wysokiński 1991 and 2011. There are numerous noteworthy publications, such as: Ostrowski and Pacanowski 2011, Ostrowski et al 2013. Geophysical methods are commonly used in hydro-engineering, e.g. stability monitoring, construction of dikes and retention tanks in the coastal zone of the " $70 \mathrm{XX}$ (e.g. Bestyński 1975).

\section{DESCRIPTION OF SELECTED FRAGMENTS OF THE PLOCK SLOPE}

\section{Plock Cathedral Basilica of the Assumption}

The slope has two drops: the first with a height of approximately $23 \mathrm{~m}$ and approximately $33^{\circ}$ inclination, the other with a height of approximately $17 \mathrm{~m}$ and $16^{\circ}$ inclination. The total height of the slope is roughly $40 \mathrm{~m}$. The extent of this part of the slope equals $125 \mathrm{~m}$. The complex of sacred buildings is located only on the upper part of the slope. At the foot of the slope runs a road. The slope is faced from south to west.

Fragment of the slope near the Basilica of Płock is not listed in the database records of the Landslide Protection System (SOPO). Location of the profile measuring ERT is shown in Fig. 2. Near ERT profile archive geologic section is located.

Stability of the slope was a subject of many publications and materials from the scientific or technical conferences in Płock. One of conferences " Displacements of Płock slope", (1998) provided geologic archive of cross-sections describing the state before geotechnical reinforcements (Fig. 3). As evidenced, the difference of the slope geometry presented in relation to that found during the measurements by ERT is significant (Fig. 6). Archive shows a cross-section of the slope in the fieldwork near the cathedral as a very steep, approximately $40^{\circ}$ and $40 \mathrm{~m}$ high.

Below the ground level there is lingering fill of $2.5 \mathrm{~m}$ in thickness. Under the fill, there is till and sand from the Vistulian glaciations of about $5 \mathrm{~m}$ in thickness. This layer is above the layers of tills and sands of Warta and Oder glaciations, which is about $25 \mathrm{~m}$ thick. At the foot of the slope (at the water level fluctuations of the Vistula river) there is gravel and sand (Great Interglacial) with a thickness of about $6 \mathrm{~m}$. Deposits of Great Interglacial linger on till and sand of South-Polish glaciations of about $15 \mathrm{~m}$ in thickness (Wysokiński 1998). Pliocene clay were not drilled.

The instability of this section (reactivation of landslide processes) of the slope was earlier reported in the eighteenth century and in the beginning of nineteenth century. Upon completion of decommissioning and stabilizing works in the second half of the twentieth century, mass movements were stopped.

\section{Maszewo (2 km north of Plock )}

The slope has two sections and goes directly down into the bank of the Vistula river. The lower part is about $13 \mathrm{~m}$ high, and angle of about $24^{\circ}$, while the second stage is about $17 \mathrm{~m}$ in height and angle of approximately $27^{\circ}$. The total height of the slope is about $30 \mathrm{~m}$. On the slope surface, in places densely overgrown with shrubs and trees, multiple deformed trees can be seen (known as "the drunk forest"), indicating the slow movement of the surface layer of the soil. In contrast, exposure of this part of the slope is from south to west, and the extension is very substantial: $250 \mathrm{~m}$. On the so-called "shelf morphology" a driveway is located, which leads to single-family residential buildings constructed in that region. According to the Landslide Protection System (SOPO), the selected portion of the slope in Maszewo is located in the area of an active landslide, Nr. 12054. That landslide has been described as a rotational landslide that covers an area of 8.29 hectares (Grabowski 2010). Location of the ERT measuring profile is shown in Fig. 4.

In this area within the depth range of reconnaissance drilling, glacial cohesive deposits are dominant (mainly tills with add of silts and sands). On the face and at the foot of each slope, colluvia sediments may be present. Slope goes down directly into the Vistula river bank where alluvial deposits 


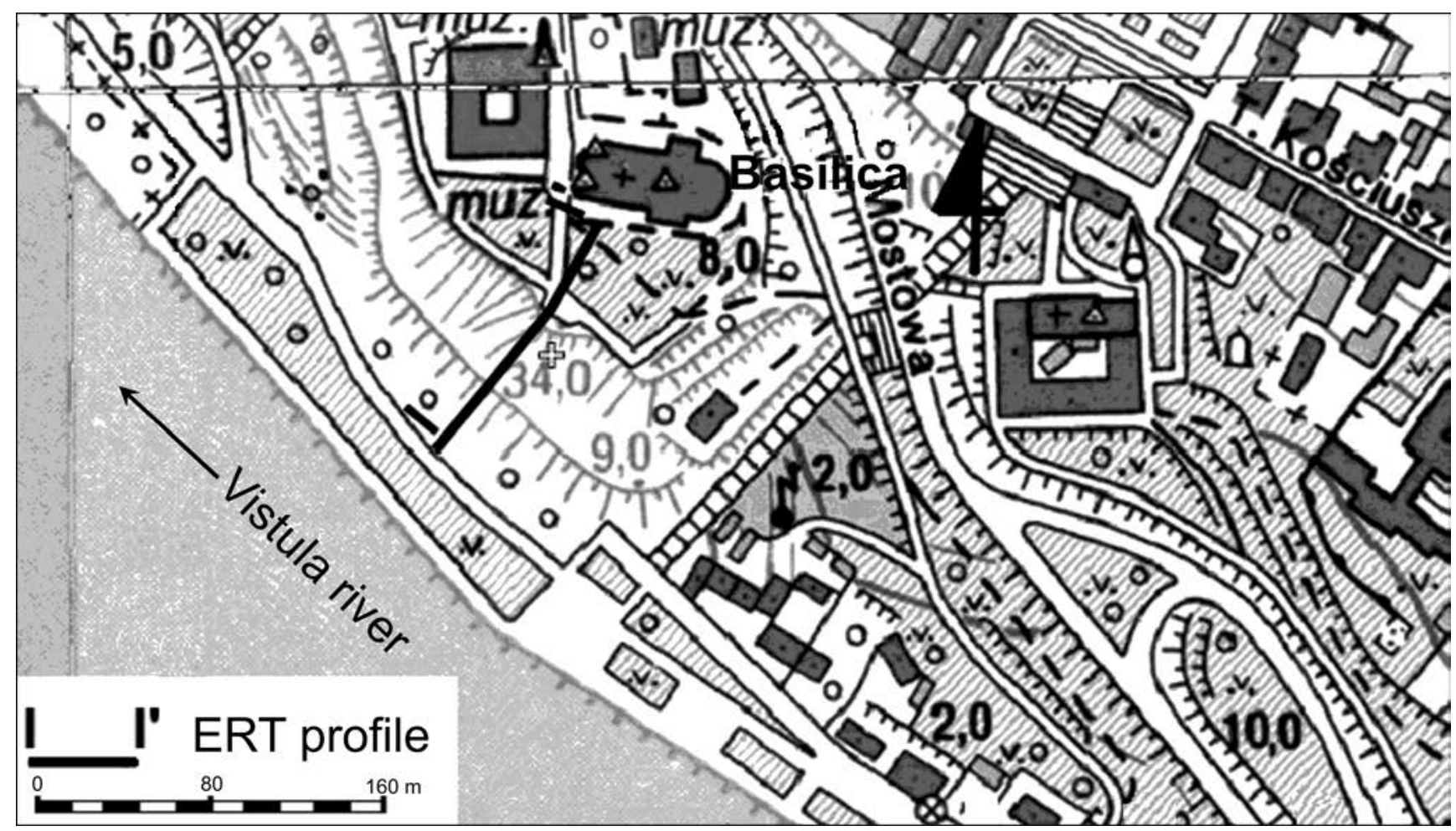

Fig. 2. Location of the ERT profile, Płock, at the level of the Cathedral Basilica of the Assumption of the Blessed Virgin Mary (www.geoportal.gov.pl).

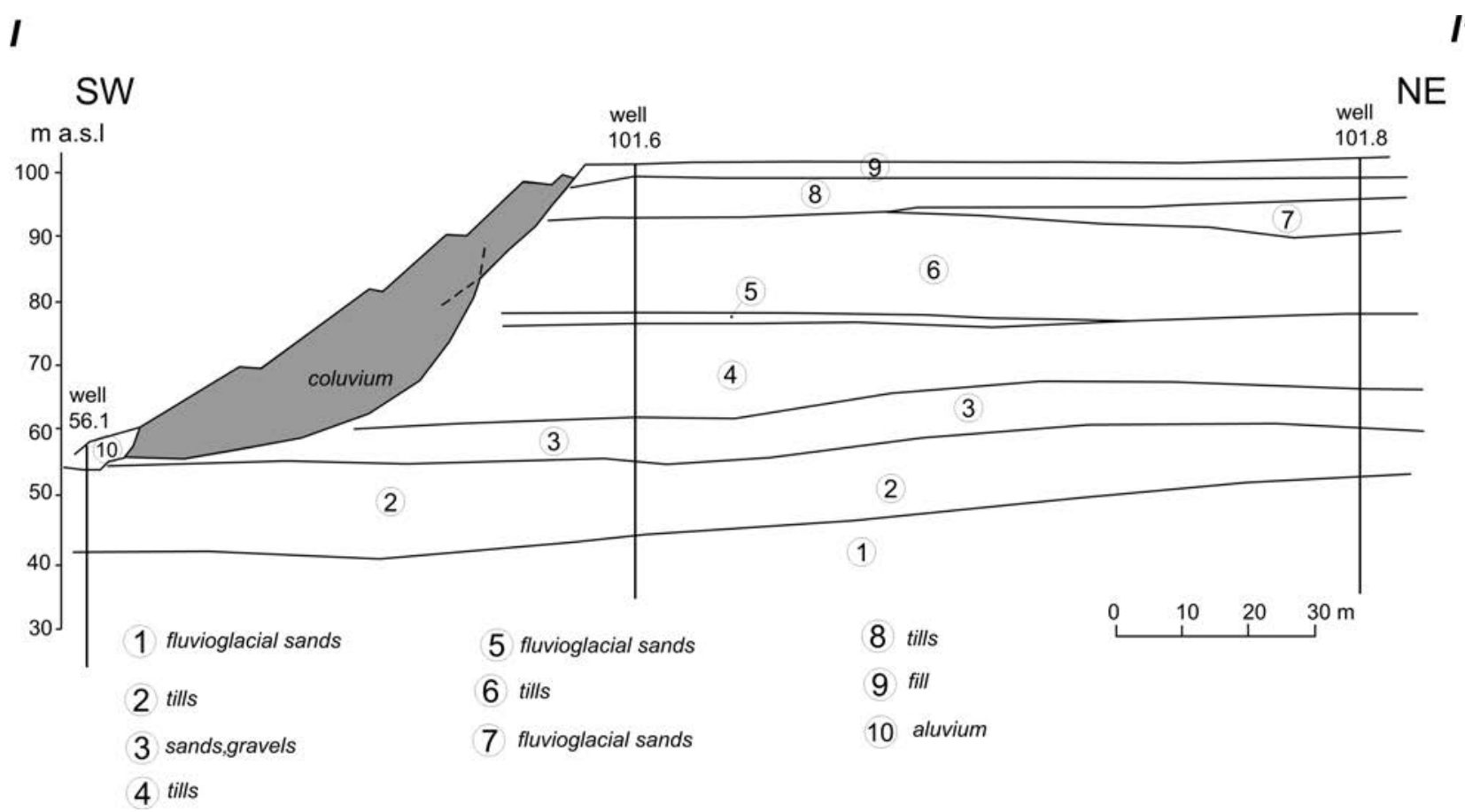

Fig. 3. Simplified geologic archive cross-section through the Płock slope near the Basilica (Wysokiński 1998).

are present. At greater depths Pliocene clay may lie (Skompski and Słowański 1962), however they were not drilled.

It should be noted that the proper interpretation of ERT measurement results requires analysis of previously conducted geological drillings and insight into cross-sections archives, which serve as a benchmark for these measurements.

\section{ANALYSIS OF SLOPE STABILITY}

Landslide activity in the section of the Płock slope near the Tumski hill was still in the twentieth century a burning problem of the city of Płock. In the second half of the twentieth century safety works were performed, which stopped 


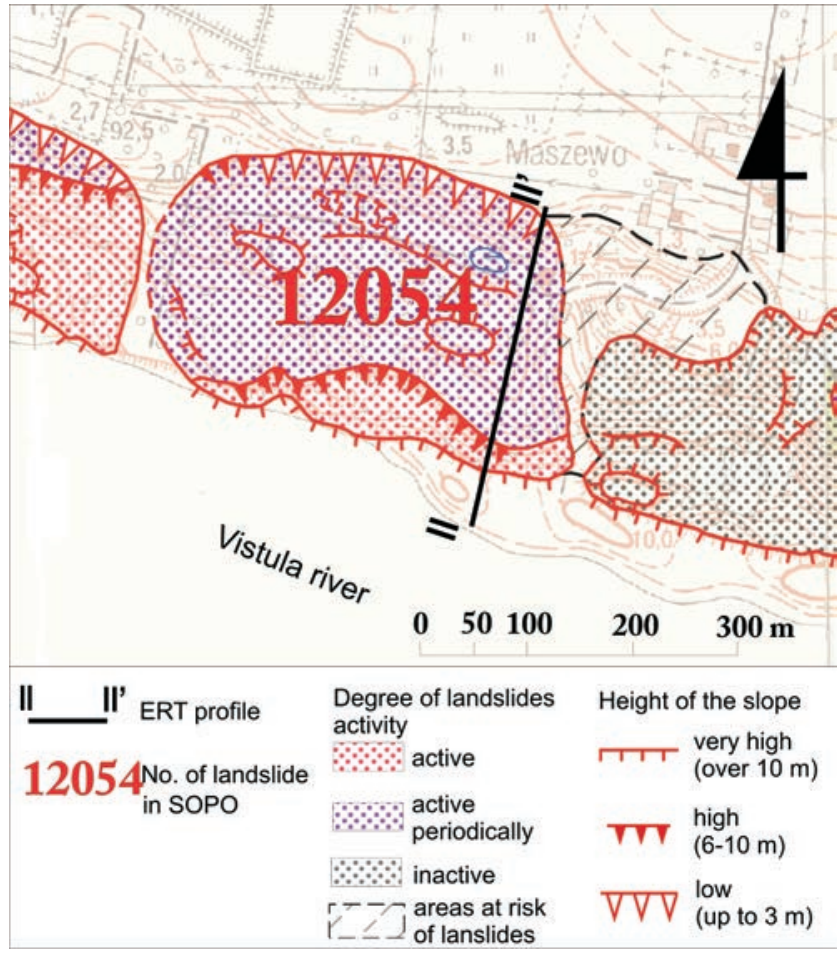

Fig. 4. Location of the ERT profile with the selected landslide Nr. 12054 (base SOPO), Maszewo.

progressing processes that would damage architectural monuments of Polish history. Currently, there are no traces of landslide activity.

Analysis of the selected fragment of the slope of Płock in Maszewo shows that in the presented section, there was a history of progressive mass movement. Today, displacements in the upper part of the slope stopped. Although, based on the deformed tree trunks and the type of soil (cohesive), it can be concurred that there is a local slow movement of the soil; creep in the lower part of the slope.

The values of the safety factor (ratio of balance) $\mathrm{F}$ for some sections of the slope of Płock summarized in Table 1.
Table 1

Safety factory calculation table

\begin{tabular}{|c|c|c|c|}
\hline $\begin{array}{c}\text { Calculate } \\
\text { cross-sections }\end{array}$ & $\begin{array}{c}\text { Value of safety } \\
\text { factor (F) }\end{array}$ & $\begin{array}{c}\text { Plausibility of land- } \\
\text { slide activity } \\
\text { (Wysokinski 1991) }\end{array}$ & Source \\
\hline \multirow{4}{*}{ Maszewo } & $\begin{array}{c}\text { Upper slope: } \\
1.35 ; \text { slope is } \\
\text { stable }\end{array}$ & unlikely & Own calculations \\
\cline { 2 - 4 } & $\begin{array}{c}\text { Lower slope: } \\
1.08 ; \text { slope is in } \\
\text { state of stability }\end{array}$ & very like & R.Mieszkowski) \\
\hline $\begin{array}{c}\text { Cathedral } \\
\text { Basilica of the } \\
\text { Assumption }\end{array}$ & $\begin{array}{c}1.7 ; \text { slope is } \\
\text { static }\end{array}$ & very unlikely & Wysokiński 1998 \\
\hline
\end{tabular}

\section{MEASUREMENTS BY ELECTRICAL RESISTIVITY TOMOPRAGPY (ERT )}

Assumptions of electrical resistivity methods were first formulated in the early twentieth century by the brothers Conrad and Marcel Schlumberger. Description of the method theory can be found, in the works of Keller and Frischknecht 1966 or Stenzel and Szymanko 1973. Electrical resistivity tomography method was developed in the late twentieth century and is widely described in the works of, e.g.: Kirsch 2009 and 1996, Loke 2012. The electrofusion research for this study was conducted by using Terrameter LS aperture manufactured by Swedish company ABEM. The main advantage of the ERT method is the possibility to develop measurements based on modeling the distribution of the circuit resistivity with a unit of rectangular blocks. Such modeling allows accurate mapping in 2D space. The study uses one of the most popular methods was used: the Schlumberger system. Measurements were carried out with intervals between the electrodes, along the profile line, amounting to 5 $\mathrm{m}$. The depth range on the field of research obtained during the measurement for diagnosis of resistivity amounted up to $30 \mathrm{~m}$. ERT measurements were captured from two selected areas (Figs 2 and 4) by using the ERT method, which were located in the vicinity of previously created geological crosssections (Figs 3 and 5).

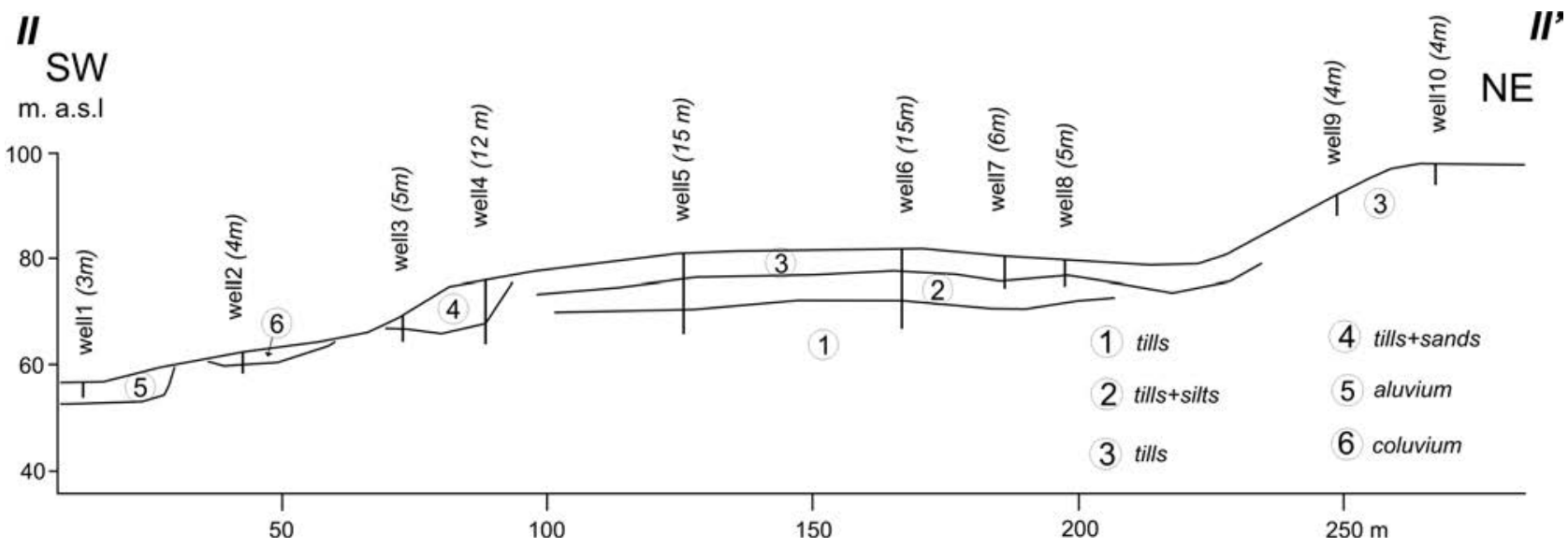

Fig. 5. Simplified geologic cross-section through the slope in Maszewo. 


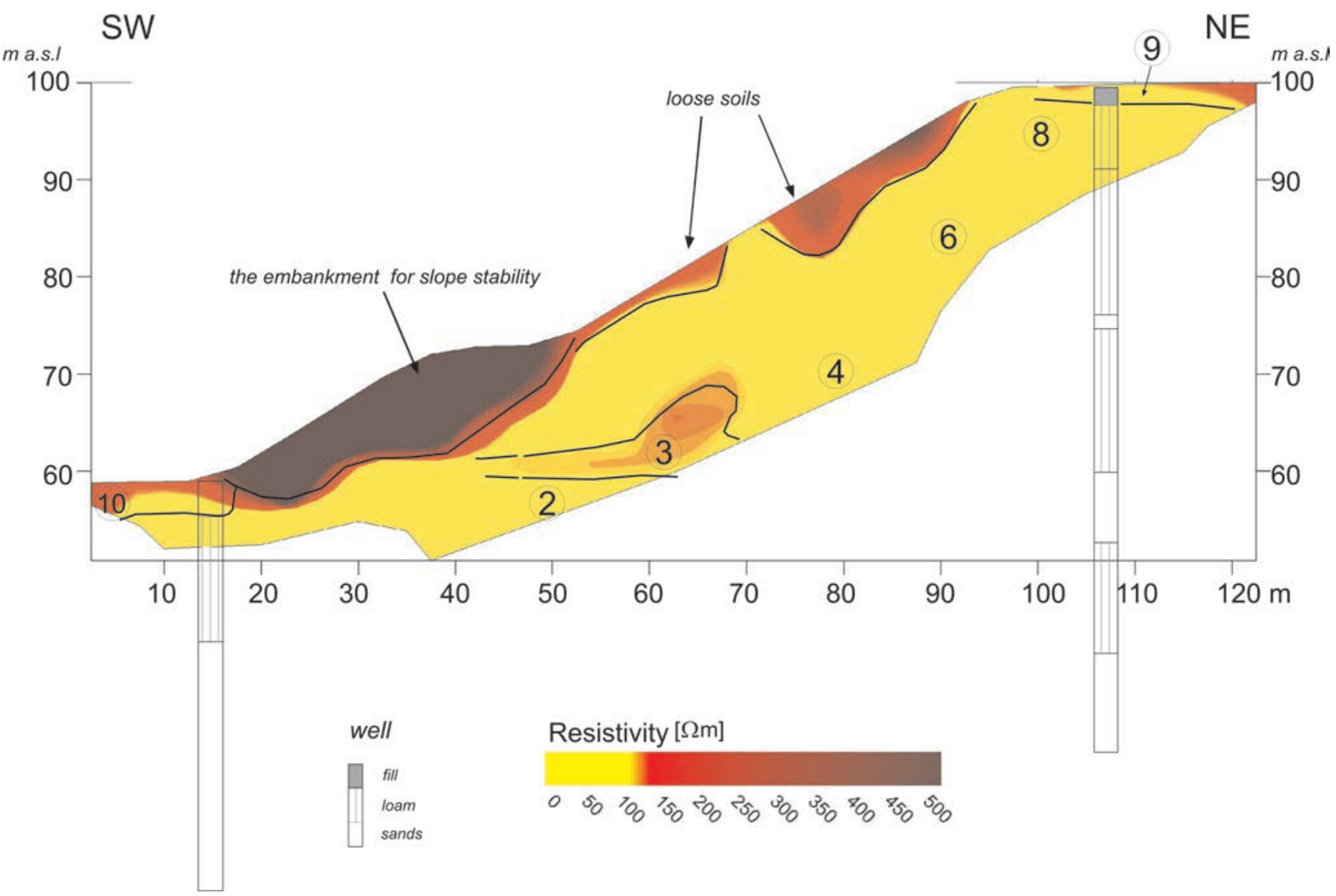

Fig. 6. Electrical resistivity cross-section made in Płock, the Basilica. The explanation as on Fig. 3.

ERT geophysical method enabled to track the distribution of the electrical resistivity of layers of soils in a two-dimensional pattern. Thanks to that a vertical section along the measuring line was obtained.

On cross-sections obtained by ERT in order to allow in-depth interpretation (including lithology correlation to resistivity), profiles of available boreholes were applied. Obtained cross-sections of land degradation in electrical resistivity in conjunction with geological interpretation are shown in Figs 6 and 7.

\section{The results of the ERT method in Plock section through the slope near the Basilica}

In the obtained electrofusion cross-section (Fig. 6) a compliance between borehole profiles with characteristic resistivity dispersion in the region of clays ( up to $90 \Omega \mathrm{m}$ ) and sands $(>120 \Omega \mathrm{m})$ can be observed very well. In the cross-section representing the base of the slope, a zone of loose soils with high resistance $(>500 \Omega \mathrm{m})$ is clearly visible. This is a safety embankment protecting the Płock slope from falling. On the face of the slope, above the embankment reinforcement, land area of higher resistivity ( $>200 \Omega \mathrm{m}$ ) can be distinguish. Geological research could not recognize the place immediately, but based on electrical resistance it can be assumed that this is loose soil and can that potentially result in mass-movement (e.g. under the influence of rainfall).

At the face of the slope there are lingering alluvial deposits with resistivity above $120 \Omega \mathrm{m}$.

\section{The results of the ERT method in a section through the slope in Maszewo}

Drillings, as well as the results of the ERT method (Fig. 7), show that the slope in Maszewo consists of cohesive deposits (clay, sandy clay) with resistances of 35-60 $\Omega \mathrm{m}$. In the upper part of the slope their resistivity is slightly elevated (separation 7 - Fig. 5). That can be associated with loosened soil or sand $(>130 \Omega \mathrm{m})$, which is noticeable only at the top edge of the slope. Trees growing on the upper portion of the slope grow straight, which means there is no landslide activity. The steep "walls" of that fragment of the slope indicate that it may be the former edge of the niche of a landslide.

The sediments forming the "shelf", at the level of several meters beneath the ground, have significantly lower resistances (separation 4). This zone extends for approximately $100 \mathrm{~m}$. Drillings have proved that these are silty clays over layered with till. Most likely, they are the historical land surface of a landslide. The argument confirming this hypothesis is the land surface morphology, typical for landslide areas (Wyso- 


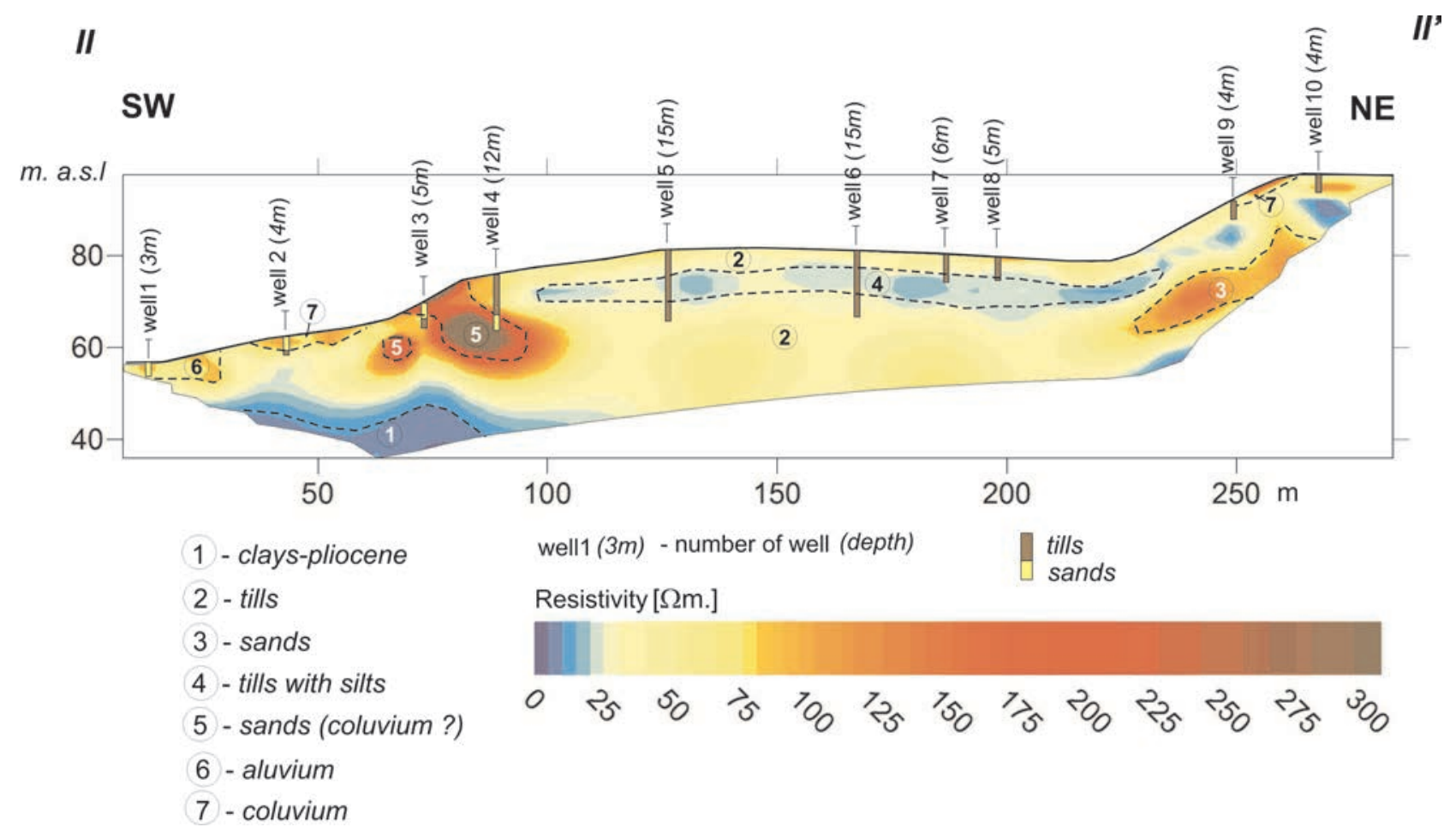

Fig. 7. Electrical resistivity cross-section performed in Maszewo.

kiński 1991), i.e. the presence of a niche, colluvium and lakes.

Within the lower part of the slope (below the shelf) two sectors of clearly elevated resistances ( $>100 \Omega \mathrm{m}$ and $>300 \Omega \mathrm{m}$ ) can be distinguished. Boreholes located in these areas have shown that these are slope sediments (colluvium). The trunks of the trees grow on this part of the slope in a distinctive way. In the bottom layer sector of ERT profile, a resistivity of around a dozen of $\Omega \mathrm{m}$ has been recorded. That can be most likely associated with Pliocene clay.

\section{SUMMARY}

By using the method of electrical resistivity tomography (ERT) it was possible to acquire the distribution of electrical resistivity in the soil in a 2D scheme for selected fragments of the Płock slope: near the Basilica and in Maszewo $(2 \mathrm{~km}$ north of Płock). The results of geophysical study have enabled significant expansion of geo-engineering analysis of the Płock slope stability with additional information about the arrangement of lithological layers and the degree of homogeneity of each layer. Due to variation of soil resistivity based on lithology, its density and moisture, potential landslides locations can be indicated. Such sites show increased electrical resistance in analyzed cross-sections.

It is important, that the results of ERT method allow determination of the approximate size of the land area with increased resistivity, and in order to verify anomalous zone, it is possible to indicate with high accuracy the area for direct verification (holes, outcrops). An important result of research by ERT on the slope in Maszewo (SOPO database which is described as a landslide Nr. 12054) is an indication of the potential slip surface of a landslide. Research by ERT made in the area of the Basilica also helped mapping the slope stabilization for the slope below the building. Landslide activity in this area would have disastrous consequences for the cathedral complex. The geophysical study shows that ERT method gives good results in comprehensive evaluation of slope stability. Separated abnormality zones with increased electrical resistivity values are usually areas of potential landslide activity. Secretion of such zones enables optimal localization of test drillings for more accurate, direct diagnosis. The ERT research can also be used to help allocating mass-movement monitoring posts, as well as enhancing preventive activities.

\section{Acknowledgements}

The authors are grateful to the Mazowsze EU Programmes Implementation Unit for financing the purchase of Terrameter LS (ABEM) equipment from RPO funds prov. Mazowieckie, year 2007-2013, Project entitled: ,Modernization and equipment of laboratories of the Faculty of Geology - The University of Warsaw, for conducting relevant research in Mazovia region - development in the field of geo-engineering environment - STAGE 1".

\section{REFERENCES}

Bestyński Z., Trojan J. 1975. Metody geofizyczne w badaniu stateczności zboczy skalnych. Badanie i prognozowanie osuwisk na zboczach zbiorników wodnych we fliszu karpackim. Konferencja PK MK WZ, IMGW, 155-170.

Bichler, A., Bobrowsky, P., Best, M., Douma, M., Hunter, J., Calvert, T., Burns, R. 2004. Three-dimensional mapping of a landslide using a multigeophysical approach: the Quesnel Forks landslide. Landslides 1, 29-40.

Bogoslovsky, V.A., Ogilvy, A.A. 1977. Geophysical methods for the investigation of landslides. Geophysics 42, 562-571. 
Friedel, S., Thielen, A., Springman, S.M. 2006. Investigation of a slope endangered by rainfall-induced landslides using 3D resistivity tomography and geotechnical testing. Journal of Applied Geophysics 100, 100-114.

Gaudio, A., Bottino, G. 2001. Electrical and electromagnetic investigation for landslide characterization. Physics and Chemistry of the Earth. Part C: Solar- Terrestial and Planetary Science 26, 705-710.

Göktürkler, G., Balk Aya, Ç., Erhan, Z. 2008. Geophysical investigation of a landslide: The Alt nda landslide Site, zmir (western Turkey). Journal of Applied Geophysics 65 (2), 84-96.

Grabowski D. 2010. Mapa osuwisk i terenów zagrożonych ruchami masowymi ziemi, skala 1:10000, powiat Płocki, Wyd. PIG, Warszawa

Hack, R.. 2000. Geophysics for slope stability. Surveys in Geophysics $21,423-448$.

Keller G.V. and Frischknecht F.C.1966. Electrical methods in geophysical prospecting. Pergamon Press Inc., Oxford.

Kirsch R., (ed.) 2009. Groundwater Geophysics, A Tool for Hydrogeology, 2ed ed., Springer. New York

Lapenna, V., Lorenzo, P., Perrone, A., Piscitelli, S., Rizzo, E., Sdao, F. 2005. 2D electrical resistivity imaging of some complex landslides in Lucanian Apennine chain, southern Italy. Geophysics 70, B11-B18.

Le Roux, O., Jongmans, D., Kasperski, J., Schwartz, S. and Potherat, P. 2011. Deep geophysical investigation of the large Séchilienne landslide (Western Alps, France) and calibration with geological data. Engineering Geology 120 (1-4), 18-31.

Loke M.H., Barker R.D. 1996. Rapid least squares inversion of apparent resistivity pseudosections by a quasi-Newton method. Geophysical Prospecting 44, 131-152.

Loke M. H. 2012. Tutorial: 2-D and 3-D electrical imagining surveys. Geotomo Software, Malaysia.

Marescot L., Monnet R., Chapellier D. 2008. Resistivity and induced polarization surveys for slope instability studies in the Swiss Alps. Engineering Geology 98 18-28.

Mauritsch, H.J., Seiberl, W., Arndt, R., Römer, A., Schneiderbauer, K., Sendlhofer, G.P. 2000. Geophysical investigations of large landslides in the Carnic Region of southern Austria. Engineering Geology 56 373-388.
McCann, D.M., Forster, A. 1990. Reconnaissance geophysical methods in landslide investigations. Engineering Geology 29, 59-78.

Ostrowski, S., Pacanowski, G. 2011. Near surface geophysical prospecting using engineer seismic and electric resistivity tomography. Bulletins of the Polish Geological Institute 446, 215-224.

Ostrowski S., Rybak-Ostrowska B., Lasocki M. 2013. Wykorzystanie przypowierzchniowych badań geofizycznych w rozpoznaniu budowy geologicznej na przykładzie stref osuwiskowych w Karpatach. Przegląd Geologiczny Tom $61 \mathrm{Nr} 1 \mathrm{r}$. 2013, 67-73.

Perrone, A., Iannuzzia, A., Lapenna, V., Lorenzo, P., Piscitelli, S., Rizzo, E., Sdao, F. 2004. High-resolution electrical imaging of the Varco d'Izzo earthflow (southern Italy). Journal of Applied Geophysics 56, 17-29.

Skompski S., Słowański W., 1962. Szczegółowa Mapa Geologiczna Polski 1:50000. PIG, Warszawa.

Socco, L. V., Jongmans, D., Boiero, D., Stocco, S., Maraschini, M., Tokeshi, K., Hantz, D. 2010. Geophysical investigation of the Sandalp rock avalanche deposits. Journal of Applied Geophysics Volume 70, 277-291.

Stenzel, P., Szymanko, J. 1973. Metody geofizyczne w badaniach hydrogeologicznych i geologiczno inżynierskich. Wyd. Geologiczne, Warszawa.

Tetegan, M., Pasquier, C., Besson, A., Nicoullaud, B., Bouthier, A., Bourennane, H., Desbourdes, C., King, D., Cousin, I. 2012. Field-scale estimation of the volume percentage of rock fragments in stony soils by electrical resistivity. Catena Volume: 92, 67-74.

Wysokiński L. (ed.) 1991. Posadowienie obiektów budowlanych w sąsiedztwie skarp i zboczy. Instrukcja nr 304. Instytut Techniki Budowlanej. Warszawa.

Wysokiński L. (ed.) 1998. Konferencja Naukowo-Techniczna: Przemieszczenia Skarpy Płockiej, ITB, Płock, 107-151.

Wysokiński L. (ed.) 2011. Ocena stateczności skarp i zboczy. Zasady wyboru zabezpieczeń. Instrukcja. Instrukcja nr 424. Instytut Techniki Budowlanej. Warszawa. 